\title{
Morpho sanguinalis
}

Beauty is in the eye of the beholder.

\section{Julie Jansen}

The first recorded sighting of Morpho sanguinalis in the Pacific Northwest occurred in 2020. Dr Fitzmorris identified it as he gazed through a pair of binoculars into his Seattle backyard. The world-renowned entomologist knew the South American butterfly well.

An unmistakable species, the Morpho was enormous, with brilliant azure wings that spanned 20 inches. Beauty was its only redeeming quality. Dr Fitzmorris had lost half his men to the insect during his last expedition to the Venezuelan jungle. The trip was a nightmare he would never forget. Morpho sanguinalis had a taste for human blood. With its mosquito-like proboscis, a group of Morphos could drain the blood from an adult human in less than an hour.

Dr Fitzmorris set the binoculars down. He rubbed his eyes and hoped it was only a hallucination. The stunning butterfly floated above a tree. On the ground below, blood dribbled from a cut on Mrs Fitzmorris's knee, injured while tending her garden. There soon appeared another Morpho, and then another, until 20 circled over his wife like hungry vultures.

"Run!" he screamed. She raised her head, her face shaded by the wide brim of a sunhat. Morpho sanguinalis had arrived, and Mrs Fitzmorris, along with the entire northwest population, was in trouble.

Climate change led to many new insect species calling the region their home: fire ants, killer bees, botflies. Although rainfall hadn't changed, within 20 years the area lost its winter chill and morphed into a hot, humid, tropical jungle. The climate was perfect for Morpho sanguinalis, but geographical barriers had kept them out. The butterfly couldn't have reached the area without human help.

The butterflies fluttered closer to his wife. He screamed at her again, but she only shrugged her shoulders, oblivious to the imminent danger. When her gaze drifted to the house her expression turned angry. Their daughter, Marny, stood outside the door in a risqué French maid's outfit clutching two large opened specimen boxes. Marny grinned as she watched the butterflies dance above her mother's head.

The horrible truth flashed before Fitzmorris's eyes. Marny was a troubled teen. She'd fallen in with a group of young women known as the Gothic Lolitas. Fitzmorris spent half his pay cheques on outfits that transformed her into a blacklipstick-wearing Little Bo Peep. Perhaps not so coincidentally, the Gothic Lolitas worshipped the Morpho's vampiric tendencies.

Marny had travelled with Dr Fitzmorris on the ill-fated trip to Venezuela. She wore those ridiculous outfits even in the jungle. Fitzmorris remembered her sewing the hem of her petticoats one night. He'd assumed she was mending a tear. Now he realized what she'd been doing she was stitching Morpho sanguinalis pupae into her skirt, where they would go undetected by customs agents at the airport. Homeland security knew how to sniff out bombs and drugs, but pupal-stage insects slipped by scot-free.

Even in the adult stage, few would suspect the high level of danger the butterfly posed. More common was that people would gawk at its beauty until the Morpho swooped down and bit them on the neck. Toxins in the butterfly's saliva had a rapid paralysing effect. With the victim rendered immobile, one or more Morphos could gorge themselves with blood. Dr Fitzmorris and Marny witnessed it first hand in the Venezuelan jungle.

Marny and Mrs Fitzmorris argued often these days. The spats were getting more and more violent. They fought that morning because of the French maid's outfit Marny insisted on wearing to school. Mrs Fitzmorris forbade Marny to leave the house until she changed. Marny refused. Rather than obey her mother, the unruly teen unleashed her prized Morphos. They were attracted to the blood flowing from the cut on her mother's knee.

Mrs Fitzmorris noticed some dark shadows moving about the ground. She glanced up and saw what looked like several birds. The underside of Morpho sanguinalis' wings was a dull brown, a trait that kept it well-camouflaged against the trunks of trees. When one of the butterflies swooped in closer, Mrs Fitzmorris saw the brilliant blue wings.

Mrs Fitzmorris gasped. She gazed every day at a picture of a Morpho. Marny kept it as a screensaver. She remembered everything Dr Fitzmorris had told her about the vampiric South American butterfly. The
Morpho was repelled by garlic. Mrs Fitzmorris grew a patch of garlic in her garden. Pollinating insects loved it. Mrs Fitzmorris pulled a stalk from the ground, and squished the pungent bulb in her palm. She smeared the muddy garlic paste over her face and neck.

The effect was immediate. The Morphos smelt it and flitted away. Mrs Fitzmorris ran to the house and into the arms of her husband.

Marny, on the other hand, was infuriated. Her plan had backfired. Her mother was alive, and she had lost her 